Note: This is an Accepted Manuscript of an article published by Taylor \& Francis

in Celebrity Studies on 1 March 2020, available online:

https://doi.org/10.1080/19392397.2020.1704380

\title{
A Venus in Marble and Bakelite: Ava Gardner and One Touch of Venus (1948)
}

One Touch of Venus (Seiter,1948) is a musical comedy starring Ava Gardner as an ancient statue of Venus brought to life in a department store. The film's release coincided with a late-1940s peak in usage of the terms 'goddess' and 'Venus' in the fan and trade press, and chimed with contemporary discourses of the 'war goddess', a figure closely aligned with the femme fatale of film noir. One newspaper described Gardner as undergoing 'the goddess build-up' for the role.

Exploring the film's promotion and reception, Felleman and Saltzberg's work on Gardner, and 1940s writing on celebrity divinisation, I discuss how UniversalInternational's campaign exploited the star's rising profile, including the Bakelite figurine of the star distributed to exhibitors, and beauty contest tie-ins where fans could measure themselves up against star and sculpture alike. This Bakelite Venus mediates between the marble fantasy of Gardner's 'Anatolean Venus', the authorship of the star, and the enveloping myth of screen stardom.

But Hollywood pedestals are built to crumble, and the constructed ideals of classical beauty are here also exposed as a commodified travesty in marble, flesh and Bakelite. While Gardner was 'built-up' as a goddess, like her peers Rita Hayworth and Maureen O'Hara, this patriarchal construct of female beauty was also repressive, disempowering and de-humanising. This article explores the 'goddess build-up' and uses the Bakelite Venus as case study into its enduring divinising, and desecrating, connotations, which still resonate in celebrity culture today.

Keywords: stardom, classicism, Ava Gardner, divinisation, sculpture, desecration 
Star 'divinisation' has played a key role in the evolving discourse of stardom since the early 1910s. It appropriated in particular from classical myth and iconography - the discourse of screen gods and goddesses, Venuses and Apollos - to establish what a star is, and how they should be seen. This also served an attempt to raise the cultural gravitas of stardom, and cinema, in the process. Although of course, this does not always work. However, in this article I am approach things from a slightly different angle to highlight that divinisation - endowing stars with pseudo-divine qualities or associations - is often, even inherently, also a process of de-sacralisation.

My case study is provided by the publicity campaign for One Touch of Venus, a 1948 musical comedy directed by William A. Seiter for Universal. The film revolves around an ancient statue of Venus (figure 1) acquired by department store owner, Whitfield Savory II (Tom Conway), which is unwittingly brought to life in the form of rising star, Ava Garner, by a kiss bestowed by timid window-dresser, Eddie Hatch (Robert Walker). Farcical events ensue as Venus pursues and then wins Eddie's affection, before she is forced to return to Olympus by Zeus, leaving her statue, and Eddie, behind. The film is freely adapted from the 1943 Kurt Weill / Ogden Nash Broadway musical of the same name, a show inspired by the 1898 British novel by F. Anstey, The Tinted Venus. The film version suffered four years of troubled development, and would remove most of the show's songs, and much of its lyrical sophistication. Mary Pickford had secured the screen rights in 1944 for a Technicolor adaptation for United Artists (FD 1944). Ginger Rogers was soon associated with Venus as well as Mary Martin, who originated the role on stage, but who pulled out after becoming pregnant. After further delays Hedy Lamarr was linked to the project in the trade press in 1947, but after fraught negotiations Pickford sold the rights to the film in a deal with United-International. Deanna Durbin was rumoured to be cast as Venus before Gardner was finally borrowed from M-G-M in December 1947, but by that point the film would no longer be in Technicolor and the budget was evidently reduced after reportedly being as high as $\$ 2,500,000$ at one point (Variety, 1944; Showmen 1945; FD 1947; Variety 1947; Showmen 1947; IEFB 1947). 
In the discussion that follows, I begin by briefly introducing the context of Venusian star discourse in the late 1940s, and the rising profile of Gardner herself, before turning to the marketing of the film and the eclectic cultural and mythical references used to engage contemporary audiences. Here I focus on a Bakelite Venus figurine circulated by the studio to exhibitors and press editors, which crystallises many of the issues at stake. While Gardner was 'built-up' as a goddess, as were her peers Rita Hayworth and Maureen O'Hara, I argue that such patriarchal constructs of female beauty are often repressive and disempowering in simultaneously deifying and, as its corollary, dehumanising female stars. Hollywood pedestals are built to crumble, and the constructed ideals of classical beauty are arguably also exposed as a commodified travesty in marble, flesh and, as we shall see, Bakelite.

\section{Venus in the 1940s}

The divinising discourse of screen gods and goddesses was established by the early 1910s, and reinforced in the 1920s, as part of Hollywood's industrial strategy to promote itself as art as well as entertainment. Motion pictures could thus be promoted as the most modern of art forms but one framed as having a prestigious cultural line going back to ancient Greece and Rome. The broad typology of mythologized celebrities that emerged were ideal fodder for the growing fan-magazine industry where they would be brought into play in half-serious tones, allowing fans to respond with admiration or incredulity; both feeding the columns of the letters pages and producing a gauge of popularity for the publicity departments. This phenomenon of star divinisation was celebrated in fan-magazines as in Photoplay's 1928 'Olympus Moves to Hollywood' feature that posed Richard Arlen and Joan Crawford as the Apollo Belvedere and Venus de Milo respectively (Waterbury 1928). It also received critical attention from early commentators such as Rebecca West in the 1920s (1929), Winthrop 
Sargeant (1947) and Parker Tyler (1971) in the 1940s, and Edgar Morin (2005) in his study of the star system in the 1950s (see also Williams 2018: 97-130). ${ }^{\mathrm{i}}$

One Touch of Venus is part of a cycle of films, and stars, aligned with the 'love goddess' or 'Venus' type predominant in the late 1940s. This is also apparent if one searches for cognate terms such as 'Sphinx', 'Siren', 'Goddess' and 'Venus' - the most prominent, and inter-related, nouns relating to female 'divinized' stardom of this period - using the Media History Digital Library's 'Arclight' application, which can visualise peaks and troughs in the use of such terms within its digitised archive of fan and industry publications (see MHDL). I do not have scope to discuss this in detail, but it is clear that there is a resurgence in terms relating to female 'divinized' stardom around 1943, rising to a peak in 1948, the year Gardener's film was released (that year there were 178 uses of the term 'goddess' in this sample, compared to 41 the previous year). At the time of writing, a search for 'Venus', limited to the peak year of 1948, brings 314 results, more than double the 138 results of 1947, and over three times the 89 results from 1946. The number falls back to 69 in 1949.285 of these results directly relate to One Touch of Venus, with entries ranging from box-office takings, promotional features, and discussions of the film and Gardner. There were also 10 Venus tie-ins for cosmetics, three astrological references, one to myth, and 15 references to other film titles. Significantly for the department store setting of our case study, Venus was being associated with Dior's 'New Look' here too, with one Variety feature describing how mannequins, based on Dior models, were being manufactured to show women - like Gardner's Venus in the film - how to 'look and stand' in New York. 'They will represent the Perfect Woman - the New Venus "fathered in Paris and born in New York"', it suggests (Caron, 1948: 55). This Euro-American hybrid neatly maps onto Hollywood's appropriation of ancient European artefacts, and their constructed 
discourses of cultural prestige at work in so many of these classical receptions. Such evidence points to the cyclical nature of star discourse as it shifts between different historical and cultural moments, production cycles, releases of individual films, and related patterns in star types and representations of gender and sexuality. Clearly, 'Venus' can be a broad term employed to describe any woman presented as being conventionally attractive in terms of looks, or one that might be if she copies a star or the right fashion mannequins.

Gardner explained in her auto-biography that: 'Hollywood... saw a lot of money in promoting me as a Goddess, and that process moved into high gear with One Touch of Venus' (Gardner 1990: 114). As she alludes, divinization is indeed an industrial process, cut from a very well-worn pattern. Gardner's star was thus not fully ascendant when she was contracted to appear in One Touch of Venus, and the film's promotion was clearly tasked to make her a leading star for M-G-M when the film was released in August 1948. Contemporary interviews, and Gardner's later autobiography, identify both this film, and Robert Siodmak's 1946 film noir, The Killers, as the two features that secured her screen reputation in the late 1940s. ${ }^{\text {ii }}$ Gardner asserted that the femme fatale Kitty Collins "“was a very, very important role" that gave her confidence with her first star billing (as the pressbook for One Touch of Venus reminded those publicizing that film [OTOV, 1948]) but also a determination to be more assertive in selecting subsequent roles that were right for her. "II was getting typed as a siren", she observed (Gardner 1948: 98). While there are strong resonances between the femme fatale siren who lures hapless men to their doom and the goddess she plays in One Touch of Venus, Gardner was evidently excited by the opportunity playing Venus gave her to develop her acting skills. In an interview with Modern Screen, provocatively titled 'Confessions of an Ex-Playgirl', Ava Gardner described the attraction that the role 
of Venus had for her as being a 'charming script' that offered her the challenge of playing comedy, and along with star billing for the first time. And in a line that does sound written by studio publicists, she adds: “"I'm only human, and female, I never said I was immune to flattery, and who wouldn't like to be picked to play Venus?"'(Gardner 1948: 98). Thus, while the film is perhaps not one of the critical highlights of Gardner's career, her headline appearance as Venus, and particularly as constructed by the film's publicity campaign, was crucial in consolidating her screen image and underpins her enduring stardom and subsequent conceptualizations of her as 'the Aphrodite of the atom-age', as one 1957 book described her (Wiseman 1957: 17).

Susan Felleman has written on how three of Gardner's early films - One Touch of Venus, Pandora and the Flying Dutchman (Albert Lewin, 1951) and The Barefoot Contessa (1954) - constitute a kind of trilogy, with classical statues providing the connective fabric. Felleman concludes that 'Ava is not merely statuesque; nor found among statues; she is a statue, born from one in the earlier film, memorialised as one in the latter' (Felleman 2006: 59). One can see the resonance between these statues. Yet Felleman doesn't link this fascinating triptych of goddesses to the wider phenomenon of star divinisation - that these films not only explore Gardner's star, but the underlying myth of stardom itself. Felleman rightly notes that the use of classical statues in these films 'seems to raise the problem of Hollywood classicism, product of Hollywood culture, a problem having to do with representation of desire' (68). This is where Gardner's star persona shapes, and perhaps cracks, the marble of the perfect Hollywood goddess. Although primarily known for The Killers, and 1950s roles such as her Academy Award nominated performance in Mogambo (1953), it is her private life, and particularly three marriages, to Mickey Rooney, Artie Shaw and Frank Sinatra, that have dominated her biography. Even at the time of One Touch of Venus, the press 
conflated her screen image as an alluring goddess of one kind or other with her private life, with references to Venus mixed in with condemnations of this same sexuality. Felleman argues that: 'The eroticization of the body in the war period and post-war movie goddess is part of a larger set of problems - social and cinematic', a product of a post-war Hollywood cinema that is 'fraught with contradictions that surface as a result of profound social and democratic changes' (66). Not least of these are the demands of patriarchal culture to relegate women to their 'proper' domestic sphere, with this 'goddess' promoted on a pedestal as a figure of powerful sexuality - Robert Walker spends much of the film cowering from the enamoured Venus - even as her agency is undermined. Here, as we shall see, the cold marble statue, and its Bakelite reproduction, provides an instructive metaphor.

\section{Marketing Venus}

Ava Gardner has been given the "“Goddess Build-up"' for One Touch of Venus, a British newspaper informed its readers, with stills of her wearing 'sweaters and brief beach-wear' exchanged in favour of her posing 'alongside plaster replicas of Venus'. This transition, it claims, enabled her to become 'Hollywood's Love Goddess - 1950 model' in its wake (DE 1950). This emphasis on new models stresses the presentness of Gardner's appeal but recognises the contrived and ironically ephemeral - for models are soon outmoded - nature of such divinization. Gardner's tagline as 'the living Venus' would retain currency through the 1950 s with the role credited by the star in a 1958 interview as establishing her "“sexy siren"” image but somewhat trapping her within it (SP 1958). The photograph accompanying that interview shows Gardner gazing at the ubiquitous replica of the Venus de Milo beneath the sub-heading: 'My Venus Pose 
Landed Me in Trouble'. While such images are contrived to bathe the star in reflected classical glory - as in Gloria Swanson's majestic pose next to a Venus in 1922 (see Williams 2013b) - here she seems to gaze suspiciously at the plaster goddess. Gardner has the star power to hold Venus aloft, but the dynamic is ambivalent. One might here recall how Mogambo depicted Gardner's character, Eloise, as a powerful woman in control of her sexuality, with cinematography that often framed her behind symbolic bars that associated her with the wild animals caged by Clark Gable's hunter. A year after Mogambo, posters for The Barefoot Contessa (Joseph L. Mankiewicz, 1954), in which Gardner notably poses for another Venus-like statue, branded her as 'The World's Most Beautiful Animal'. Such tag-lines dehumanise the star even as they purport to raise her onto the Hollywood pedestal.

Screenland (1948), running a full-page ad for One Touch of Venus (Figure 2), also declared that 'Ava Gardner has been made a full-fledged star by her studio, MetroGoldwin-Mayer'. Its gossip pages added that she was the 'most sexy star to hit the MGM lot since those early Joan Crawford days', perhaps an allusion to the Venus imagery that first publicised Crawford. Like those measurements of Crawford and Arlen being literally measured-up against the gods by Photoplay, the pseudo-science of measurements was deployed by the publicity department to naturalise the association with Venus. The press-book thus asserted that 'Because of her perfect proportions Ava Gardner is known as "The Modern Venus"'. The corollary of this imagery, of course, was the question to be posed to the audience: 'Do you Measure Up?' The Motion Picture Herald reported on how the campaign was rolled out in Tampa, Florida, with the 'exact measurements of "Venus"' being broadcast on radio to 'feminine' cinema patrons so they could compare themselves (MPH 1948). We might call this 'Goddess Pattern No.1', an exploitation strategy that used the same methods as Hayworth's Down 
to Earth (Alexander Hall, 1947). ${ }^{\text {iii }}$ For Gardner's film, a tie-in sponsored by underwear manufacturer Venus Foundations, Inc., launched a 'Miss American Venus' campaign, running contests in cities across the country (Showmen 1948b). In order to be able to step onto the winning pedestal to receive $\$ 1000$ in cash and a trip to Hollywood, the winner's 'beauty and figure measurements' merely needed to 'most closely resemble those of the famed Anatolian Venus' featured in the film. Lest any fans should actually match this fictional archetype, the sculptor of the film's Venus, Joseph Nicolosi, was quoted to endorse Gardner as the perfect Venus, securing the uniqueness of the star amid a potential nation of copies. As the trade paper's sub-header put it, this was all 'Grist for the Showmanship Mill'. This publicity had the intended impact on Gardner's image. On a promotional trip to London, The Star (1948) newspaper announced her as ‘Ava Gardner - choice of artists and sculptors', alongside commodifying 'views of Venus'. Such marketing could be reported as news under the increasingly thin veil of respectability provided by the archaeological conceit framed by the press-book. 'Studio tape-measure experts have been comparing her figure to that of the Venus de Milo', the paper declared as if relating a scientific discovery, with Gardner forced to indulge the ignominious request of its reporter for her to describe her own vital statistics. Under the guide of celebrating beauty, the star, and her female fans, were thus induced to selfcommodify their bodies to promote the film. This brings us to the film's key image: Gardner as Venus.

As Gardner puts it in her autobiography, in One Touch of Venus 'I played literally the ancient goddess of love' (Gardner 1990: 115). This 'literal' aspect is most concretely understood in the form of the statue of Venus / Gardner that comes to life in the film's department store, and this projection of fantastical classicism onto the star body brings us to the sculpture at the centre of the film and its marketing. 
The press lingered salaciously on the story of Gardner having posed, initially reluctantly, topless for the sculptor, Joseph Nicolosi, when her bikini top had apparently spoiled the authenticity of the desired classical lines. Nicolosi was best known for works including the 1928 Italian War Memorial, the Victory at Morristown, which portrays the winged goddess with a flowing chiton not unlike the film's Venus. Gardner recalls being proud of the nude statue when it was unveiled, but that Hollywood's hypocrisy meant that the producers wanted sex but couldn't handle female sexuality:

Then came the explosion. A nude statue! Who said anything about nudity? Tits! Didn't anyone tell you that tits aren't allowed in a Hollywood film? It doesn't matter how beautiful they are, it's immoral and indecent. Plus, the goddamn statue has to come to life on screen. Do you want us to be accused of corrupting the whole of America? (Gardner 1990: 115)

A clothed version of the sculpture was hastily commissioned, leaving the original to the fervent imagination of the press. Indeed, the idea of Gardner posing for the statue was widely used to legitimate discussion of her body. One Australian paper uncomfortably evoked the casting couch in its revelation that Gardner: '...was required to reveal to Producer Lester Cowan what an internationally famous sculptor, Joseph Nicolosi, pronounced "the most perfect figure on the screen to-day." To say that Miss Gardner filled the physical requirements is putting it mildly...' (Narandera Argus 1948). One might here recall a line from the stage musical's title song, 'One Touch of Venus', regarding the power of the ancient Venus: 'In a world controlled by gods, / She open'd up her bodice, And equalized the odds'. However, Hollywood's 'Venus' clearly felt that 
the odds remained stacked against her.

British distributor, Eros Films, issued a publicity sheet that claimed that Gardner had been cast by producer Lester Cowan following his decision 'that the part should go to the Hollywood actress who most closely resembled the famous statue of the Anatolian Venus', with the 'revelation' that she was 'practically identical' to the 'original statue' securing her the contract (Eros 1950). This is virtually the same text as was used in marketing the 'American Venus' campaign. However, fake patina is being added very freely to this imagery for the purportedly ancient 'Anatolian Venus' acquired by Whitfield Savory II in One Touch of Venus does not match any known classical type. If one undertakes an image search for 'Anatolian Venus', the results feature predominantly Neolithic mother goddesses. The specificity of the name, like the whiteness of its image, serves as an authenticating discourse to fabricate the sculpture's artistic and historical aura, and those of Gardner in the process. The press were confused as to whether the inspiration for the film's statue was an actual Anatolian Venus, the Venus de Milo, or Gardner herself. The Showmen's Trade Review offered the helpful clarification that the statue modelled on Gardner 'differs from the original Venus de Milo in that the new figure has arms' (Showmen 1948a). Again, this asserts a notion of the original, and also that that original is the Venus de Milo. As Elizabeth Prettejohn observes, since its discovery in 1820, that sculpture's image was circulated through all available $19^{\text {th }}$ century forms of reproduction, including photography, which was essential to 'its celebrity as an antique' (Prettejohn 2006: 235). It thus overtook the fame of the Venus de Medici, the previous exemplar of Venusian beauty. The fame of the ancient sculpture bathes the film version, however divergent, with a certain cultural aura by association. But if aura is not sufficiently established on artistic grounds, it was reported that the producers have had the statue 'insured for $\$ 200,000$ and placed a 24- 
hour guard on set in which it is prominently displayed' (Showmen 1948a). As Julian Stringer wrote with regard to the past's authenticating patina: 'To remain culturally valued, objects must also show evidence of being maintained with care and the right technical instruments' (Stringer 1999: 210). The aura of Gardner's sculptural doppelganger is here almost literally policed into existence.

While the classical world is generally received as a reassuringly stable reference point in the historical imaginary and an epoch of artistic virtuosity and sexual freedom (for men at least), it is anything but. The privileged artefacts that define the 'classical', certainly from Hollywood's carefully cherry-picked view, are relatively few in number, and have gone in and out of fashion even over the past 200 years. It is significant that many of the artworks, principally statues, we take to embody the classical ideal are often Roman copies of earlier Greek works. Beard and Henderson illuminatingly describe this as an example of: 'the classical insight of all classicism: to copy an original is to re-create the original; but it is also to create an original' (Beard \& Henderson 2001: 6). This was true in antiquity as now. Since the $18^{\text {th }}$ century, reproductions of the most celebrated sculptures have been mass-produced for the homes of Grand Tourists and collectors and in antiquity small statuettes of religious and secular nature, were also made in a variety of materials, including cheap terracotta for votive offerings, or more expensive materials for display in the home. ${ }^{\text {iv }}$ Thus while the cinematic 'Anatolian Venus', and particularly its Bakelite copy, are easily labelled kitsch - sacrilege in the face of high classical art - this belies the fact that Gardner's pose as Venus is part of a long cultural history of copying and ancient and modern framings. ${ }^{v}$

The 1898 source novel makes some play on the apparent inability for the public to distinguish between the 'original' goddess herself and kitsch copies when a customer, 
spotting it in a shop, dismisses the genuine antiquity as a "cheap, tawdry imitation of the splendid classic type' (Anstey 1898: 82). The film never questions the authenticity of its statue, indeed it accentuates it even as the plot parallels the film's marketing in that the ancient Venus is placed on a pedestal only to bathe Savoy's store in its aura. One Touch of Venus also exploits the unsettling sexual politics of its story as a subtext for its humour. Savory's sassy assistant, Molly Stewart (Eve Arden), welcomes a rare moment when her boss is distracted from the Venus, she quips 'at least it took your hand off cold marble for a while', highlighting his physical, as well as intellectual and financial, infatuation with the sculpture. Her line 'I can see you bouncing little statues on your knee', is startlingly surreal in its vivid reference to Pygmalionism as a sexual fetish, defined by sexologist Havelock Ellis in 1905 as 'falling in love with statues... a rare form of erotomania founded on the sense of vision and closely related to the allurement of beauty' (Ellis 1905: 188). Eddie also refers to a tactile relationship with Venus exclaiming, 'Just a few minutes ago you were cold marble... I could touch you!', as he realises that his unsolicited touch was transgressive. These ambivalent responses to Venus' nudity - at once objectifying and prudish - have long visited the reception of female classical nudes. Mitchell Havelock's study of Praxiteles' Aphrodite of Knidos a figure showing Aphrodite at the moment she realises she is being spied upon while taking her ritual bath - explores how Victorian audiences were unsettled by a tension arising from the duality of the sacred and profane symbolised by the sculpture (Mitchell Havelock 1995: 43). ${ }^{\text {vi }}$ Claimed as the first full-size sculpture of the female nude, the sensuality of the figure affected the Victorian reputation of Praxiteles and particularly due to conjecture about his relationship with the model for Venus, Phryne, who may have been a prostitute. This historical line of misogyny is not disconnected from the siren image under which Gardner was being promoted at this time, where the sexualised 
persona constructed for her was also used against her. Indeed, the fascination expressed by journalists with Gardner having posed nude for Nicolosi's statue carries an echo of the sensation surrounding Praxiteles' ancient Venus.

The star's private life was thus constructed to authenticate her siren image, but often not in a way that was willing to credit her with any agency, as in Louella Parsons' snide remark from the pages of Modern Screen one month before production of the film began in February 1948: 'A while ago, Ava Gardner said she was going to skip men for her career. Since then, she's been out with almost every unattached male in town' (Parsons 1948). Parsons' observation reinforces the double standard in which 'unattached' men clearly have more freedom than unattached women and suggests that Gardner does not take her work seriously. There are also ambivalences in the gender dynamics of the Greek myth of Galatea and Pygmalion, which inspires the story. The sculptor, Pygmalion, is credited with having created the illusion of perfect form and beauty in his statue, Galatea, but it is the female divine power of Venus that actually allows life to be breathed into the artwork at Pygmalion's kiss. ${ }^{\text {vii }}$ This was a favourite subject in Victorian visual culture, appealing to the contemporary male heteronormative view of women that was, as Richard Jenkyns notes, 'at once oppressive and fantastic' (143). This perhaps also describes the frame in which One Touch of Venus, and the cinematic and Bakelite statue were viewed. Gardner's living sculpture / goddess is a fantasy projection of beauty and sexuality (but surely not exclusively for male viewers), but her agency is ultimately curtailed: Eddie bestows her humanity with a kiss, and it is head Olympian, Jupiter, who actually intervenes in her narrative to give, and apparently remove, her life. We now need to turn to discuss how these discourses can be seen to shape the form of the Bakelite Venus itself. 


\section{The Bakelite Venus: Icon and Object}

In September 1948, Film Daily reported what it termed 'the newest trend in film merchandising tie-ups', namely studios sending promotional objects to the press and exhibitors to create awareness of their forthcoming releases (FD 1948). In this case we find standing on the editor's desk: ‘A Venus statuette, sent along by Ava (Venus) Gardner as "a vibrant, high voltage voluptuary—a veritable preview of "One Touch of Venus"'. Alliterative hyperbole aside, we here encounter an object that idealises Gardner and simultaneously, and literally, objectifies her (Figure 2). Felleman has described the film's Anatolian Venus as being 'thoroughly indigestible as a veritable antiquity' (61), and it does frustrate historicisation. It is also, as I will now indicate, a curious Bakelite expression of star divinisation that can illuminate many of the mechanisms that underlie such constructions as well as the different interpretations they foster.

The Anatolian Venus places the emphasis very much on the neo in neoclassicism, with the neo taking the form of Ava Gardner. With its elongated body and windswept robe, the statuette echoes the streamlined aesthetic of interwar art moderne. Indeed, the kind used to dress many 1920s and 30s movie sets (See Fischer 2003). Gardner's Venus comes full circle in this sense, and as a copy of a copy, it belongs to a long history of loss, rediscovery, and appropriation. Film Daily did not describe what the Venus, which stands some $30 \mathrm{cms}$ tall is made from, but close inspection of one of the Venuses reveals it to be comprised of a dense resin, probably Bakelite, the first synthetic plastic of early $20^{\text {th }}$ century mass-production (fig.3). It is a fitting synthesis of ancient and modern. Made to look carved, the figure has the near heaviness of stone and so aspires to a certain quality, despite its factory origins. It is made to sit on a desk or in a cabinet, just like reproductions of its sacred classical ancestors, and mediates between 
the marble fantasy of the 'Anatolean Venus', the authorship and nascent persona of Gardner herself, and the wider enveloping myth of screen stardom itself.

This is a very different sculpt from the Venus sculpture seen in the film, although Gardner also posed with the Bakelite version in many publicity photos, as if endorsing it. Unlike the brilliantly white film version (which reproduces the problematic, and historically inaccurate, construction of classical $=$ white over recent centuries), its colouring is defiantly earthy, and unusually recalls the terracotta votives of antiquity. While the robe hangs vertically and statically in the original, in the figurine the drapery suggests movement. Much indeed like the 1940s 'Varga Girl' pin-ups that famously adorned Second World War aircraft, a type which Maria Elena Buszek frames as 'a sort of modern war goddess' sometimes including a Venus among their number, complete with clinging clothing to resemble 'the wet peploi of Hellenistic marble goddesses' (2006: 206, 187). Unlike the film version, Venus appears to be stepping off the pedestal with her lower body and left leg. This takes a cue from the Venus de Milo, whose missing left foot would have slightly protruded over the edge of her pedestal. Yet here, due to the elongation of the body to contrive a streamlined effect, the effect is awkward, particularly as her torso and head seem to lean back. Indeed, that step forward is more associated with Nike as in the $2^{\text {nd }} \mathrm{CBE}$ Hellenistic terracotta figure of Nike now at the Museum of Fine Arts, Boston (Nicolosi having already sculpted a Winged Victory, as we have seen) (Nike). ${ }^{\text {vii }}$ Most recognisably, it recalls the Winged Victory of Samothrace herself - a classical work widely appropriated in the wake of the Great War - indicating the imminent arrival of the goddess, her pose capturing the moment of action transferring to stillness to deliver a cry of victory at the end of battle. The Bakelite Venus seems strangely caught between pose and movement, as if the sculpture caught Gardner either claiming, or resisting, the pedestal. There is another fascinating 
connection to a key publicity image from Down to Earth the previous year (DTE 1947:

22). Hayworth's Terpsichore is seen dancing down a flight of steps, her right foot extended before her. Next to her is superimposed a full-sized Venus de Milo; in contrast, Hayworth appears flexible, dynamic and defiantly alive (see Williams 2018: $120-123)$.

Gardner's Venus seems more contained but possesses a certain imperious dignity. Indeed, her pose is best appreciated from a level plane, or from slightly below, as if gently commanding the onlooker into a deferential, if not subordinate, position. ${ }^{\text {ix }}$ There are other subtle differences between Gardner's screen and Bakelite Venuses; Gardner no longer has her hand so provocatively on hip in the Bakelite version, and her hands have relaxed fingers swept backwards, with her hair also more swept-back and 'classical' in contrast to the greater accentuation of late-1940s coiffure on screen. While the figurine does emphasise Gardner's breasts, they also are streamlined in the manner of an Art Moderne figurine, and the wind-blown lines of the figurine's drapery also cling more around the waist. The most significant difference is this is a threedimensional art object occupying the space of the viewer, a Venus to be appreciated inthe-round as in Hellenistic sculpture; indeed, the film's title is inscribed around its circular base, inviting it to be turned.

\section{Debasing Venus}

As we have seen, the marketing of Gardner as 'Hollywood's Love Goddess - 1950 model', heralds her arrival to the Hollywood pantheon, but carries the tacit acknowledgement that this position is merely rented. Moreover, the movie gods are placed on pedestals carefully designed to rock a little to reveal human flaws, and even 
fall. This was vividly portrayed in a 1927 Picture-Play graphic, with a female 'not so very much more than human' star clinging precariously to a swaying column (Reid 1927). Fan-magazines built their readership through features and letters pages that alternately deified and desacralized, often in the turn of a page, to engage and provoke discussion. Conceptually, this de-bases the star. The pedestal, literal and metaphorical, is a structural prop which elevates the sculpture above the realm of the viewer. It needs to wobble a little for authenticity and 'human' identification, but not crumble or fall entirely. The Pygmalionesque art of bringing art to life is exemplified in cinema, and embodied most vividly in the form of the star, who as a figure of identification and desire, and yet one who is also absent yet present (Ellis 1992), speaks to the strange proximity of life and death attendant in the image, and between the idealised body and cold, lifeless, marble in the case of sculpture. The Aphrodite of Knidos, sexually assaulted in the ancient accounts of Pliny and Lucian - relating the tale of a young man so taken by Venus' beauty that he conducts a physical act of passion with the statue - is an extreme example (Beard \& Henderson 2001: 128-131). But in modern patriarchal culture, likening a female star's beauty to marble, as so often happens, is a construction that can instantly be spun into terms of abuse.

Thus, the flipside of the 1940s figure of the War Goddess, powerful, inspirational and sexually self-confident, and a fantasy for men and women alike, is a figure contrived to be passive and silent, a sculpture returned to clay or unhewn marble. Greta Garbo famously refused to play the Hollywood publicity game, but her aloofness became a strangely ethereal commodity to market, her absence cast in marble and exploited by her press. Thus we have her rumored fiancé, John Gilbert, purportedly opine after her reported jilting of him at the altar that 'She is like a statue. There is something eternal about her... She is capable of doing a lot of damage...' (Photoplay 
1927). Photoplay printed a somewhat unsettling account attributed to Laurence Oliver, describing Garbo's apparent insensibility to his screen wooing, having been originally cast opposite her in Queen Christina. Olivier complains that in response to his touch Garbo "“was as frigid to my embrace as if she were a woman of stone" (Maxwell 1934: 33). It is revealing that the source of this power, the performance of these female stars in enacting the mythic image of ancient women, is then used against them if the cold marble doesn't warm to the right, male, touch. If Venus rebels, or Galatea denies the grasp of Pygmalion, she must be cast back into cold stone. Indeed, Jupiter does exactly that, and apparently returns Venus to stone with a thunderclap at the end of One Touch of Venus. Her curious return to the department store as the human 'Venus Jones' in the film's coda, reads as a consolation prize for the male protagonist; she has been apparently stripped of her divine powers to become his mortal girlfriend.

It is worth pausing for a moment to reflect on the wider context of this divinising discourse for Gardner's contemporaries in the 1940s, particularly in terms of the unsettling implications of the imagery of warm / cold marble. Female stars of the period did speak out. One remarkable piece of star defiance came from Irish-born Hollywood star, Maureen O'Hara, whom John Ford originally wanted for Gardner's part in Mogambo (Bean and Uzarowski: 116). The famously red-haired star was herself described by Modern Screen as a 'green-eyed Venus' (Fitzsimons 1948: 37), but highlighted a different side to this sculptural imagery in an interview reported around the world in 1945. She states:

'I am a helpless victim of a Hollywood whispering campaign. Because I don't let the producer and director kiss me every morning or let them paw me they 
have spread the word around town that I am not a woman - that I am a cold piece of marble statuary. I guess Hollywood won't consider me as anything except a cold hunk of marble until I divorce my husband, give my baby away and get my name and photograph in all the newspapers. If that's Hollywood's idea of being a woman I'm ready to quit now' (LE).

This quote went viral on social media in November 2017 in the context of the \#MeToo movement, ${ }^{\mathrm{x}}$ and shows O'Hara framing her treatment by Hollywood as the disturbing flipside to the divinising discourses we have seen used to build up stars such as Gardner.

Clearly, the sexual objectification of the female star on and off-screen exemplified by the ambivalent icon of the 'high voltage voluptuary' Bakelite Venus, has remains highly relevant to the creation and reception of female celebrity. Just as the star as a form of living sculpture must not step too far from the pedestal carved for her, so too she must not age and deviate from fixed ideals of beauty. In ancient artefacts, the markings of patina on their surface testify to the authenticity of age. While broken statues were first deemed in need of restoration that would allow their beautiful completeness to be appreciated (see Lowenthal 2015), this view gave way to an appreciation for the look of age as being of aesthetic value in itself and, as in the case of the broken limbs of the Venus de Milo, the time-worn signs of age rendered the sculptures even more beautiful. This is not the case for female stars. If their bodies show the signs of age or illness, it is usually constructed not as patina, but tarnish. Take, for example, an awful 1981 article in the Daily Mail, which revisited Rita Hayworth's 1940s image in order to weaponise it against her. Announcing Hayworth going public 
about having Alzheimer's Disease, the headline declared: 'When a Love Goddess Fully Crumbles' (Lewin 1981).

More generally, as Rebecca West argued in the 1920s, screen gods and goddesses are to be worshipped, but are also willed to fail and die, and thus bring redemption in the form of a 'sacrificial victim'. This is usually female, West asserts. The mourning of these figures, she suggests, brings a kind of strange collective comfort, and a form of secular atonement that in the ancient world would be 'specifically religious' (West 1929: 32, 34). 'It certainly looks...', West opined in 1929: ‘...as if Hollywood were young America's Olympus, and its stars its gods” (31). Hollywood's divinised stars have to be carefully calibrated for largely secular audiences, with the line between a worshipped screen divinity and pagan idol carefully, but often knowingly, negotiated. This is aided by the fact that the ancient pantheon of Greek and Roman gods, like those of ancient Egypt and other antiquities, have themselves become desacralised through time and the fall of great civilisations, and largely consumed as archaeological, and artistic, artefacts. Films such as One Touch of Venus play on this knowledge, and deploy their cinematic, Pygmalionesque, magic in apparent aid to a nostalgic yearning to return those lost gods to us, in forms shaped to stimulate the novelty of the present.

Even the most divinised stars, if one were to scrutinise them archaeologically back through centuries of classical reception, would have their base layers in some desecrated ancient site, itself buried for posterity in the dirt by serendipity or design, natural cataclysm (as in the case of Pompeii and Herculaneum), or the arrival of a new religion that swept away the old idols. Sacralising and desecrating are in this sense, mutually dependent but, as this case-study of Gardner and One Touch of Venus has hopefully illustrated, it is in the treatment of female stars that it is often most 
pronounced.

The Bakelite Venus is a commodified product specifically designed to stand watchfully on the table of those tasked with selling the film, and its star, as if tacitly directing their decisions. It remains tied to Gardner through innumerable stills of its creation, and she to it, and it contains within its pose the ongoing performance and cultural work of innumerable women, artists, and models, before it; and it would have no meaning without this palimpsestic work. In the body of the Bakelite Venus, we are viewing an ancient goddess as worshipped in antiquity, and later a secular object marshalled to promote Western ideals to construct an aura of art, beauty and femininity. It is the most ridiculous, kitsch, gimmick; an ephemeral caprice of late 40s merchandising that has somehow survived to become an artefact. But it is also an object lesson in the material, and immaterial, nature of idolatry and secularisation and the ongoing dynamics of star divinisation and desecration. The Venus is a palimpsestic emblem of classical ideals that are so often aspired to, and a symbol of the consequences; the more someone is perceived to take the form of a statue, the less their humanity needs to be recognised.

In being an apparently concrete, and yet fabricated archetype, the Anatolian Venus is a fitting metaphor for the unreasonable ideals imposed on female stars and cinemagoers. At the same time, one must also not lose sight of the fact that the Venus is also an icon fashioned in collaboration with Gardner herself as an artist, and a lasting celebration of her intervention into a history of Venuses. As ambivalent as it, it remains a lasting part of her body of work. Thus, while Jupiter may have returned Gardner's living Venus to stone with a thunderclap in One Touch of Venus, her Bakelite figure can still stand proudly, if not victorious, by herself. 



\section{References}

Anstey, F., 1898. The Tinted Venus: A Farcical Romance (illustrated by Bernard Partridge). London and New York: Harper.

Bean, K., and Uzarowski, A., 2017. Ava: A Life in Movies. Philadelphia, PA: Running Press.

Beard, M and Henderson, J., 2001. Classical Art: From Greece to Rome. Oxford: Oxford University Press.

Bulfinch, T., 1979. Myths of Greece and Rome. New York: Penguin [first published 1855].

Buszek, M.E., 2006. Pin-up Grrrls: Feminism, Sexuality, Popular Culture. Durham: Duke University Press.

Campbell, G., 2007. The Grove Encyclopedia of Classical Art and Architecture, Volume 2, Oxford: Oxford University Press.

Caron, L. 1948. Plenty of Showmanship with That New Look: From Shuberts to TV. Variety, 3 March, pp.2, 55.

DE, 1950. Ava Gets the "Goddess Build-up". Daily Express, 22 March, unpaginated clipping, BFI Library, London.

DTE, 1947. Down to Earth pressbook, BFI Library.

Dyer, R. (1998). [First pub. 1979.] Stars. London: BFI.

Ellis, H., 1905. Studies in the Psychology of Sex, 7 vols. 1897-1928 (Vol. 4). Philadelphia: F.A. Davis, p.188. 
Ellis, J., 1992. Stars as a Cinematic Phenomenon, Visible Fictions (London: Routledge, 1992), pp.91-108.

Eros, 1950. Beauty by the Inch. Film News sheet from Eros Films Ltd., London, dated 21 June. BFI Library, Ava Gardner clippings.

Felleman, S., 2006. Art in the Cinematic Imagination. Austin: University of Texas Press.

Film Bulletin, 1948. Production and Release Record. Film Bulletin, 16 February, p.23.

FD, 1944. Mary Pickford Buys "Venus” for UA pic. Film Daily, 6 October, pp.1, 8.

FD, 1947, Film Daily, 18 September, p.5.

FD, 1948, Film Daily, 10 September, p.4.

Fischer, L., 2003. Designing Women: Cinema, Art Deco and the Female Form. New York: Columbia University Press.

Fitzsimons, R., 1948. Goddess in the Family. Modern Screen. February, pp.36-37, 71, 74.

Gardner, A., 1948. Confessions of an Ex-Playgirl. Modern Screen, November.

Gardner, A., 1990. Ava-My Story. London: Bantam Press.

IEFB, 1947. Independent Exhibitors Film Bulletin, 31 March, p.19.

Jenkyns, R., 1980. The Victorians and Ancient Greece. Oxford: Basil Blackwell.

Lewin, D., When a Love Goddess Fully Crumbles. Daily Mail, 10 April. Unpaginated clipping. BFI Library. 
LE, 1945. Star's Love Strike, The Liverpool Echo, 30 May 1945, p.2.

Lowenthal, D., 2015. The Past is a Foreign Country: Revisited. Cambridge: Cambridge University Press.

Maxwell, V., 1934. The Amazing Story Behind Garbo's Choice of Gilbert. Photoplay, January, pp.32-33, 101.

MHDA. Media History Digital Library: http://mediahistoryproject.org [Accessed 30 November 2018].

Mitchell Havelock, C., The Aphrodite of Knidos and Her Successors. Ann Arbor: University of Michigan Press.

Morin, E., 2005. The Stars. Minneapolis: University of Minnesota. [originally published 1957].

MPH, 1948. 'At Home or Abroad It's Exploitation', Motion Picture Herald, 6 November, p.36.

Narandera Argus, 1948. One Touch of Venus. Narandera Argus and Riverina Advertier (NSW), 10 December, p.2.

Nike. Flying Nike (Victory), Burr, Terra-cottas from Myrina (MFA), no. 065: https://www.mfa.org/collections/object/flying-nike-victory-152131 [Accessed 29/11/18].

OTOV, 1948. One Touch of Venus pressbook, BFI Reuben Library, London.

Parsons, L. 'Good News', Modern Screen, January 1948, p.10.

Photoplay, Up Speaks a Gallant Loser. Photoplay, February 1927, pp.32-33, 130. 
Prettejohn, E., 2006. Reception and Ancient Art: The Case of the Venus de Milo. In: C. Martindale and R. F. Thomas eds. Classics and the Uses of Reception. Oxford: Blackwell, pp.227-249.

Reid, M., 1927. Don’t Annoy the Stars! Picture-Play, August, p.83.

Sargeant, W., 1947. The Cult of the Love Goddess in America. Life, 10 November, 8096.

Screenland, 1948. Screenland, October.

Showmen, 1945. Showmen's Trade Review, 24 February, p.28.

Showmen, 1947. Showmen's Trade Review, 27 December, p.34.

Showmen, 1948a. Venus gets arms. Showmen's Trade Review, 14 February, p.30.

Showmen, 1948b. Grist for the Showmanship Mill. Showmen's Trade Review, 18 September, p.15.

Star, 1948. The Star, 4 August.

Stringer, J., 1999. “The China Had Never Been Used!”: On the Patina of Perfect Images in Titanic. In: K.S. Sandler and G. Studlar eds. Titanic: Anatomy of a Blockbuster. New Brunswick, NJ, and London: Rutgers University Press, pp.205-219.

SP, 1958. Ava Gardner on the Snares of Stardom. Sunday People, unpaginated clipping, BFI Library, London.

Tyler, P., 1971. Magic and Myth of the Movies. London: Secker \& Warburg. Variety, 1944. Variety, 20 September, p.3. 
Variety, 1947. Variety, 27 August, p.223.

Waterbury, R., 1928. Olympus Moves to Hollywood. Photoplay, April, pp.34-36, 92.

West, R., 1929. New Secular Forms of Old Religious Ideas. The Realist: A Journal of Scientific Humanism, Vol.1, No.3, pp.25-35.

Williams, M., 2013a. Film Stardom, Myth and Classicism: The Rise of Hollywood's Gods. Basingstoke: Palgrave Macmillan.

Williams, M., 2013b. Gloria Swanson as Venus: Silent Stardom, Antiquity and the Classical Vernacular. In: P. Michelakis and M. Wyke, eds. The Ancient World in Silent Cinema. Cambridge: University of Cambridge Press, pp.125-144.

Williams, M., 2018. Film Stardom and the Ancient Past: Idols, Artefacts and Epics. London, Palgrave Macmillan.

Wiseman, T., 1957. The Seven Deadly Sins of Hollywood. London: Oldbourne Press. 


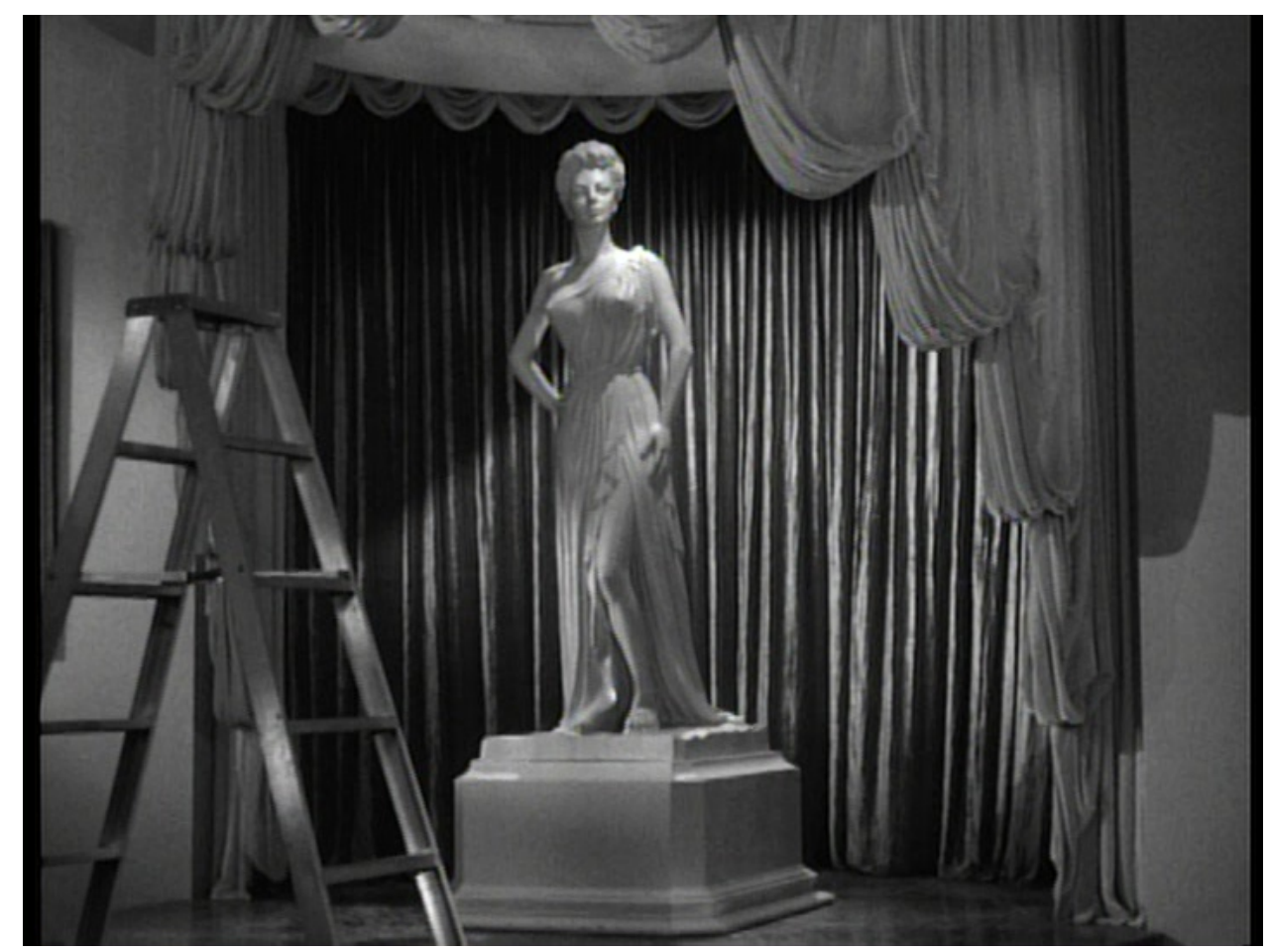

Figure 1 The 'Anatolian Venus' as seen in One Touch of Venus (1948). Screen capture. 


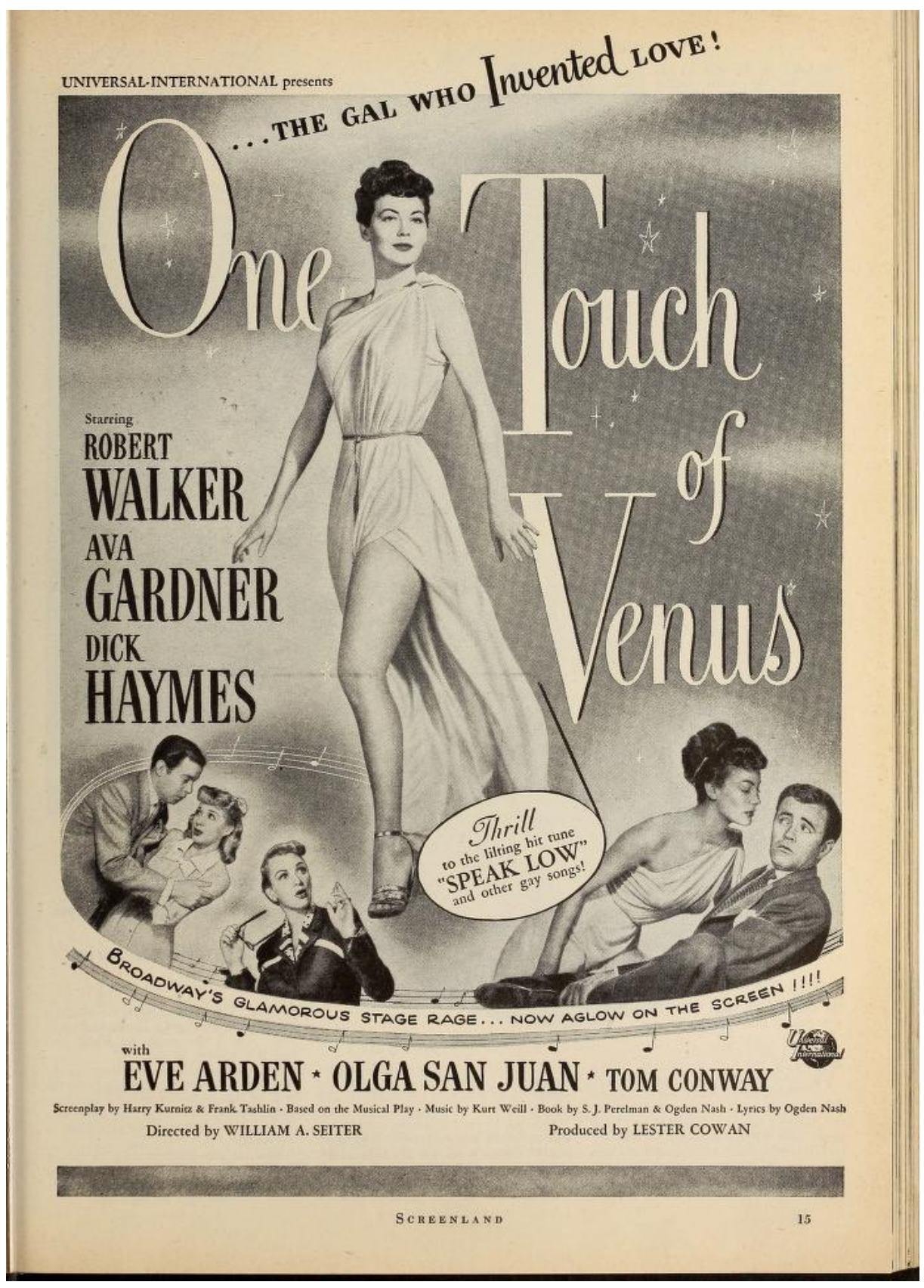

Figure 2. One Touch of Venus advertisement. Screenland. October 2048 (Media History Digital Library). 


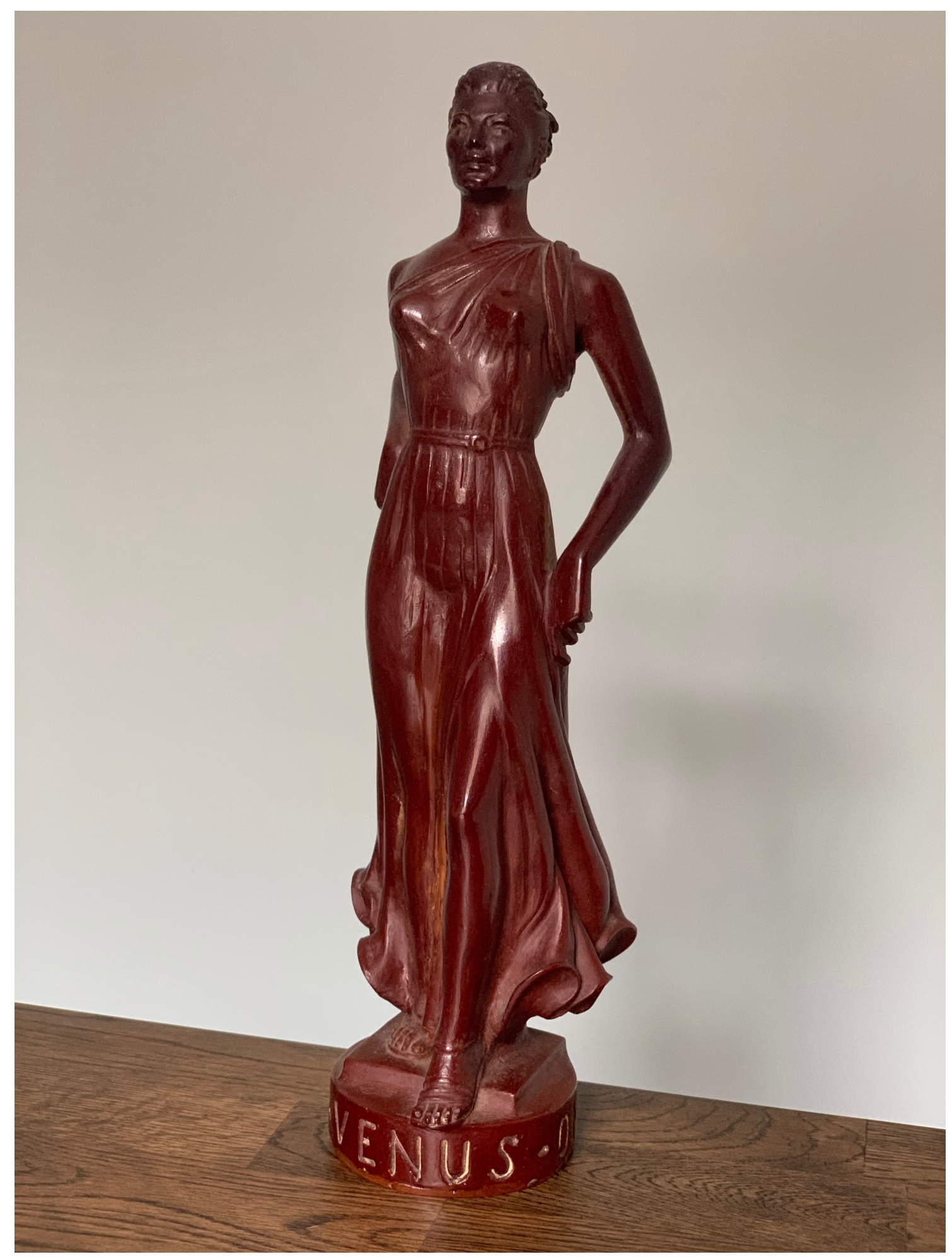

Figure 3. The Bakelite Venus (author's collection). 
Thanks to editors Sean Redmond and Romana Ando, the anonymous reviewers, and the Celebrity Studies journal team and the participants of the 2018 conference where a version of this paper was presented. Particular thanks to Lucy Bolton, David Cobbett, Andrew Moor, Louise Revell, and the great students at Southampton with whom I have discussed the Bakelite Venus.

${ }^{\text {i }}$ For further discussion of this context with respect to Rita Hayworth and the 'Love Goddess' concept, see Williams 2018, pp.97130. Dyer (1998) also summarises later critical discussion of stardom's apparent historical shift from 'gods to mortals', pp.2123.

ii See Williams 2018 for more on the link between the femme fatale and the figure of the 'war goddess'.

iii Similar strategies were used in the marketing of Tarzan films, where male cinemagoers were asked to compare their bodies to the likes of Johnny Weissmuller and Buster Crabbe. See Williams 2018, pp. 59-93.

iv Gordon Campbell, The Grove Encyclopedia of Classical Art and Architecture, Volume 2 (OUP, 2007), p.644.

${ }^{\mathrm{v}}$ For further discussion on these ancient/modern framings, see Williams 2013a, pp.1-24.

${ }^{\text {vi }}$ Notably, Gardner is first seen in Mogambo when Eloise is discovered in the shower by Clark Gable's Victor. Thanks to Lucy

Bolton for her comments on Gardner's wider image, and for sharing her paper, 'Virgins, Whores, Actresses: Grace Kelly and Ava Gardner in Mogambo', BAFTSS Conference, London 24-26 April 2014. As Bolton argues, in these later roles Gardner's performance, and persona, would foreground the tensions in her characters.

vii There are many variants of this myth, but this is the basic version usually recounted, and I here draw on Bullfinch's popular Victorian account (Bullfinch: 88).

viii See: 'Flying Nike (Victory), Museum of Fine Arts, Boston: https://www.mfa.org/collections/object/flying-nike-victory-152131 [Accessed 17 April 2019].

ix Thanks to my postgraduate 'Screen Stars' students for the comment on the viewing angle of the figure.

x See@JRhodesPianist on Twitter on 4 Nov 2017. Thanks to Andrew Moor for highlighting this newspaper story on Instagram when it went viral (@andrewmoor,6 November 2017). 